\title{
Gene Fusion
}

National Cancer Institute

\section{Source}

National Cancer Institute. Gene Fusion. NCI Thesaurus. Code C20195.

Any hybrid gene formed from two previously separate genes. Such fusions occur as a result of translocation, intersititial deletion or chromosomal inversion, and often result in gene products with functions different from the two fusion partners. Gene fusions are associated frequently with hematological cancers, sarcomas and prostate cancer. 